CLINICAL STUDY

\title{
High prevalence of genu varum/valgum in European children with low vitamin D status and insufficient dairy products/calcium intakes
}

\author{
A Voloc ${ }^{1}$, L Esterle ${ }^{2,3,4}$, T M Nguyen ${ }^{4}$, O Walrant-Debray ${ }^{4}$, A Colofitchi ${ }^{5}$, F Jehan ${ }^{4}$ and M Garabedian ${ }^{4}$ \\ ${ }^{1}$ University of Medicine and Pharmacy 'Nicolae Testemitanu', Chisinau, MD 2001 Moldova, ${ }^{2}$ Inserm U986, Hospital St Vincent de Paul, 82 Avenue \\ Denfert-Rochereau, 75014 Paris, France, ${ }^{3}$ Reference Center for Rare Diseases of Calcium and Phosphorus Metabolisms, GH Cochin/St Vincent de Paul, \\ 75014 Paris, France, ${ }^{4}$ Inserm U561, GH Cochin/St Vincent de Paul, 75014 Paris, France and ${ }^{5}$ Department of Parasitology, National Center of Preventive \\ Medicine, Chisinau, MD 2028 Moldova
}

(Correspondence should be addressed to L Esterle at Inserm U986, France; Email: laure.esterle@inserm.fr)

\begin{abstract}
Objective: The prevalence of lower limb deformities physiologically decreases after 5 years of age. It remains high in some tropical and subtropical regions where it has been associated with severe vitamin D deficiency, low calcium/milk intakes, malnutrition, and/or fluoride overexposure. Very little data is available in apparently healthy Caucasian children and adolescents.

Design: We evaluated the prevalence of genu varum/valgum and other clinical symptoms, and assessed vitamin D status and markers of calcium metabolism in 226 apparently healthy European full-time boarders (7-16 years) seen during winter-spring and fed a cereal-based diet with little access to meat, milk, and dairy products. A cohort of 71 white children and adolescents hospitalized for acute illness served as age-matched controls.

Results: Association studies showed a high prevalence of lower limb deformities (36\%) and higher alkaline phosphate activities in the $21 \%$ of children and adolescent full-time boarders with serum $25-(\mathrm{OH}) \mathrm{D}$ levels $\leq 30 \mathrm{nmol} / \mathrm{l}$, and low serum calcium in the $74 \%$ of boarders with $25-(\mathrm{OH}) \mathrm{D}$ levels $\leq 50 \mathrm{nmol} / \mathrm{l}$, compared with boarders with higher vitamin D status. No such anomalies were found in the control cohort despite lower serum 25-(OH)D levels.

Conclusions: Low 25-(OH)D levels, at least during winter-spring, combined with additional risk factors such as very low calcium/milk intakes and possibly digestive disorders, are associated with an increased risk of genu varum/valgum in European children and adolescents. Thus, dietary fortification, or supplementation with vitamin D, may be recommended, at least during the winter, to European children and adolescents with either none or insufficient calcium/dairy product intakes.
\end{abstract}

European Journal of Endocrinology 163 811-817

\section{Introduction}

Serum 25-(OH)D levels are considered the best marker of vitamin D status and have been commonly used to assess the prevalence of vitamin D deficiency/insufficiency in healthy children and adolescents (1-9). But a clear understanding of the clinical significance of given concentrations of circulating $25-(\mathrm{OH}) \mathrm{D}$ levels is still lacking (10-13), and the vitamin D status needed for an optimal bone health and calcium homeostasis during growth is still in discussion, with proposed 25-(OH)D cutoff values ranging from $25-30$ to $70-90 \mathrm{nmol} / \mathrm{l}$ (2, 6-9, 14-16).

To define an optimal vitamin $\mathrm{D}$ status necessitates the systematic use of external international controls to test the validity of the $25-(\mathrm{OH}) \mathrm{D}$ assay and permit comparisons of the results obtained in the different laboratories $(13,17)$. It may also depend on the criteria selected to evaluate bone health, either biological (levels of serum calcium, serum PTH, and/or of markers of bone metabolism), radiological (bone mineral content or density at appendicular or trabecular sites), or, less frequently, clinical (lower limb deformities for example). So far, the lower limb deformities attributed to vitamin D and/or calcium deficiency have mostly been observed in children and adolescents living in Africa, Asia, or the Middle East $(11,18-24)$, and the sporadic cases reported in Europe, America, and Australia habitually concern recently immigrated children or offspring of immigrant parents from Asia, Africa or the Middle East $(11,25,26)$. Its prevalence is considered to be low in children and adolescents of Caucasian origin $(27,28)$, but studies are scarce and possible interplays with calcium intakes have not been considered, despite the 
emerging evidence that calcium deficiency may lower the threshold under which vitamin D status becomes insufficient to ensure an optimal mineralization of the growing skeleton $(2,11)$. In the present work, we evaluated lower limb deformities and biochemical markers of calcium metabolism in a homogeneous cohort of 226 European children and adolescents receiving a cereal-based diet with low milk/high fiber intakes. We also measured serum 25-(OH)D levels, using the International External Quality Assessment Scheme for Vitamin D metabolite (DEQAS), in order to estimate optimal levels of 25-(OH)D for bone health in Caucasian children with very low calcium/dairy product intakes.

\section{Subjects and methods}

\section{Subjects and recruitment}

The study included all $(n=226)$ apparently healthy children and adolescents ( 97 girls and 129 boys, aged 7-16 years) seen in the course of a regular medical and biological survey during the winter-spring months (January to April) while staying as full-time boarders in a Moldovan boarding school (Orhei, latitude, $47^{\circ} \mathrm{N}$ ). They stayed at this boarding school during the academic year, but lived in a rural family environment in the summer. Only children with known chronic disease and/or body measures below or above 2 s.D.s were excluded from the study. Seventy-one age-matched controls ( 34 girls and 37 boys) had an identical clinical and biochemical survey while hospitalized during the same period for acute respiratory diseases in the Municipal Clinical Children's Hospital $n^{\circ} 1$ of Chisinau (Moldova, $47^{\circ} 21^{\prime} \mathrm{N}$ ). They lived in a family of urban environment and had no known renal, endocrine, neurologic, or other chronic pathology.

All blood samples were collected during a systematic, diagnostic, or hematological survey, and approval of a local ethical committee, as well as oral consent of the children, their parents, or teachers was obtained.

\section{Dietary intake}

Full-time boarders were given one unique menu at each meal, including weekends. They had a cerealbased diet with little access to meat, milk, and dairy products. The CIQUAL table of food nutritional composition (http://www.afssa.fr/TableCIQUAL) was used to evaluate dietary intakes from 1 week menus given to all boarders at the time of the survey. Average daily intakes were the following: - total protein, $75 \mathrm{~g}$ $(2.5 \pm 0.4 \mathrm{~g} / \mathrm{kg}$ b.w per day for children and $1.8 \pm 0.3 \mathrm{~g} / \mathrm{kg}$ b.w per day for adolescents), including animal proteins, $24 \mathrm{~g}$; energy, $2842 \mathrm{kcal}$; phosphates, $921 \mathrm{mg}$; magnesium, $255 \mathrm{mg}$. Calcium daily intakes were low (493 mg including $69 \mathrm{mg}$ as milk and dairy products), but vitamin D intakes were high $(1.23 \mathrm{~g})$. Dietary information was not available for the hospitalized controls seen in Chisinau.

\section{Clinical examinations and anthropometric measurements}

One of the authors (AV) examined all 297 children and adolescents. Bone densitometry was not available, and skeletal X-rays were not performed in healthy boarders for ethical reasons, but intercondylar (IC) and intermalleolar (IM) distances were measured in them standing with either knees or ankles just touching: genu varum or valgum was defined as IC or IM $>5 \mathrm{~cm}$. Term, birth height, and weight were drawn from individual files available for each child. Height and body mass index (BMI) were evaluated both as absolute value and as $z$-scores, in comparison to WHO reference growth curves for sex- and age-matched children (29). Several other clinical features were noted, including bone pain and scoliosis (Table 1), and the presence of gastrointestinal

Table 1 Clinical characteristics of the two Moldovan cohorts. Values are expressed as mean \pm S.D. or as percentage of subjects with clinical symptoms or intestinal parasitosis in the two study groups. Comparisons were made using the Student's unpaired $t$-test (mean values) or the $\chi^{2}$-test (incidence).

\begin{tabular}{|c|c|c|c|}
\hline Population & $\begin{array}{l}\text { Rural boarding } \\
\text { school }\end{array}$ & $\begin{array}{l}\text { Urban } \\
\text { controls }\end{array}$ & $P$ values \\
\hline$n$ & 226 & 71 & \\
\hline Age (years) & $11.4 \pm 1.8$ & $11.1 \pm 2.4$ & \\
\hline Prepubertal (\%) & $52 \%$ & $46 \%$ & \\
\hline Sex (\% males) & $57 \%$ & $52 \%$ & \\
\hline \multicolumn{4}{|l|}{ Birth parameters } \\
\hline Term (weeks) & $39.4 \pm 0.8$ & $39.2 \pm 1.6$ & \\
\hline Birth weight (kg) & $3.11 \pm 0.42$ & $3.08 \pm 0.56$ & \\
\hline Birth length (cm) & $50.5 \pm 2.3$ & $50.4 \pm 2.1$ & \\
\hline \multicolumn{4}{|l|}{ Anthropometry } \\
\hline BMI (WHO z-score) & $-0.205 \pm 1.041$ & $-0.471 \pm 1.141$ & \\
\hline Children $(n)$ & $\begin{array}{c}-0.325 \pm 1.107 \\
(118)\end{array}$ & $\begin{array}{c}-0.261 \pm 1.228 \\
(33)\end{array}$ & \\
\hline Adolescents $(n)$ & $\begin{array}{l}-0.440 \pm 0.898 \\
\quad(108)\end{array}$ & $\begin{array}{l}-0.682 \pm 1.023 \\
(38)\end{array}$ & \\
\hline Height (WHO z-score) & $-0.721 \pm 1.054$ & $-0.024 \pm 1.051$ & $<0.0001$ \\
\hline Children & $-0.088 \pm 0.964$ & $-0.155 \pm 1.101$ & \\
\hline Adolescents & $-1.009 \pm 1.126$ & $0.106 \pm 1.000$ & $<0.0001$ \\
\hline \multicolumn{4}{|l|}{ Clinical symptoms (\%) } \\
\hline Bowed legs & 15 & 7 & \\
\hline Scoliosis & 11 & 8 & \\
\hline Bone pain & 8 & 3 & \\
\hline Hypocalcemic seizure & 1 & 4 & \\
\hline Poor dental health & 83 & 80 & \\
\hline Dental caries & 10 & 11 & \\
\hline Gastrointestinal & 66 & 75 & \\
\hline Intestinal parasitosis (\%) & 49 & 63 & \\
\hline Enterobius vermicularis & 40 & 20 & 0.0017 \\
\hline Ascaris lumbricoides & 4 & 14 & 0.0104 \\
\hline Trichuris trichiura & 2 & 14 & $<0.0001$ \\
\hline Giardia lamblia & - & 15 & \\
\hline Polyinfection & 3 & - & \\
\hline
\end{tabular}


parasites was investigated using standard coprological methods for Enterobius vermicularis, Giardia lamblia, Ascaris lumbricoides, and Trichuris trichiura.

\section{Biochemical analyses}

Laboratory variables were assayed in the Chisinau hospital and included serum calcium, phosphate, magnesium, protein, creatinine, hemoglobin, glucose, alkaline phosphatase, and ALT/AST transaminase activities. Serum 25-(OH) vitamin D levels were assayed in serum samples stocked at $-20{ }^{\circ} \mathrm{C}$ at the Saint Vincent de Paul Hospital (Paris) using in-house chromatographic competitive protein binding assays with the DEQAS continuous external quality assessment of the 25-(OH) vitamin D assays (30). Samples were measured together with 20 DEQAS controls (range: 9-79 nmol/l). Values were $-0.11 \pm 0.72$ s.D. units (mean \pm s.D.) from all the laboratory means for each control. PTH and bone markers were not measured because assays were not available locally and because it could not be established that serum samples were kept at optimum conditions during storage and transport to France.

\section{Statistical analysis}

Normally distributed variables are reported as mean \pm S.D. Independent unpaired t-test was used to compare pairwise normally distributed continuous variables. Significant differences between groups of $<30$ subjects were verified by using the non-parametric Mann-Whitney $U$ test. Comparisons of prevalence between groups were tested by the $\chi^{2}$-test. All analyses were performed using the Statview 5.0 software (Abacus Concepts Inc., Berkeley, CA, USA). A $P<0.05$ was considered statistically significant.

\section{Results}

\section{Clinical and biochemical characteristics}

The 226 full-time boarders and 71 hospitalized agematched controls had comparable anthropometry at birth and before puberty (Table 1). But male and female adolescent boarders had shorter height, compared with hospitalized controls and to WHO reference growth curves. The two Moldovan cohorts had poor dental health and a high prevalence of gastrointestinal symptoms, mainly multiple, but also isolated nausea $(17 \%)$ and isolated abdominal pain (20\%). Parasitic infections were frequent, with significant differences in the parasites identified (Table 1). Both populations showed a low prevalence of scoliosis and bone pain (below 10\%), but genu varum/genu valgum was frequently observed in the boarding school (15\%), even though the difference was not significant with the incidence observed in the control cohort (7\%).
Compared with age-matched controls, boarders had lower mean serum levels of calcium, magnesium, and hemoglobin, and higher mean serum levels of phosphates (Table 2). In addition, boarders had lower serum creatinine levels before puberty, and higher alkaline phosphatase activity during puberty, compared with age-matched controls (Table 2). A search for hepatitis B in the boarding school had been negative one year before the present study, but a transitory liver impact of the mebendazole treatment, received by the boarders for their parasitosis 2 weeks before the blood test, cannot be excluded, thus complicating the interpretation of circulating alkaline phosphatase activities in this cohort. Yet, no correlation was observed between serum alkaline phosphatase and AST, or ALT, transaminase activities in boarders or controls before or during puberty.

\section{5-(OH)D status}

Children and adolescents seen in the rural boarding school between January and April had a mean \pm s.D. serum $25-(\mathrm{OH}) \mathrm{D}$ levels of $44 \pm 16 \mathrm{nmol} / \mathrm{l}$, with respective prevalence of $25-(\mathrm{OH}) \mathrm{D}$ values $\leq 30$, $\leq 50$, and $\leq 75 \mathrm{nmol} / \mathrm{l}$ of 21,74 , and $97 \%$. This vitamin D status was higher than that measured in control children and adolescents living in the Chisinau city, either in apartment $(35.6 \pm 1.8 \mathrm{nmol} / \mathrm{l})$ or individual houses $(37.0 \pm 2.3 \mathrm{nmol} / \mathrm{l})$. It was not influenced by pubertal maturation but was influenced by sex: female boarders had lower mean values than males $(40.2 \pm 14.8$ vs $46.5 \pm 16.0 \mathrm{nmol} / \mathrm{l}, \quad P=0.0031)$ and a higher prevalence of $25-(\mathrm{OH}) \mathrm{D}$ levels $\leq 30 \mathrm{nmol} / \mathrm{l}$ (30 vs $15 \%, P=0.0093)$.

Table 2 Biochemical profile (mean \pm s.D.).

\begin{tabular}{|c|c|c|c|}
\hline Population & $\begin{array}{l}\text { Boarding } \\
\text { school }\end{array}$ & $\begin{array}{l}\text { Urban } \\
\text { controls }\end{array}$ & $P$ values \\
\hline$n$ & 226 & 71 & \\
\hline Children $(n)$ & 118 & 33 & \\
\hline Adolescents $(n)$ & 108 & 38 & \\
\hline Proteins $(\mathrm{g} / \mathrm{l})$ & $69 \pm 11$ & $69 \pm 8$ & \\
\hline $\mathrm{Hb}(\mathrm{g} / \mathrm{l})$ & $11.2 \pm 1.1$ & $11.9 \pm 0.4$ & $<0.0001$ \\
\hline Glucose $(\mathrm{mmol} / \mathrm{l})$ & $4.2 \pm 0.8$ & $4.3 \pm 0.7$ & \\
\hline Children creatinine $(\mu \mathrm{mol} / \mathrm{l})$ & $41 \pm 12$ & $54 \pm 10$ & $<0.0001$ \\
\hline $\begin{array}{l}\text { Adolescents creatinine } \\
(\mu \mathrm{mol} / \mathrm{l})\end{array}$ & $58 \pm 13$ & $60 \pm 11$ & \\
\hline Total calcium $(\mathrm{mmol} / \mathrm{l})$ & $2.14 \pm 0.31$ & $2.29 \pm 0.23$ & 0.0007 \\
\hline Corrected $\mathrm{Ca}(\mathrm{mmol} / \mathrm{l})^{\mathrm{a}}$ & $2.22 \pm 0.31$ & $2.36 \pm 0.24$ & 0.0025 \\
\hline Phosphates (mmol/l) & $1.36 \pm 0.38$ & $1.22 \pm 0.23$ & 0.0072 \\
\hline Magnesium (mmol/l) & $0.70 \pm 0.14$ & $0.83 \pm 0.18$ & $<0.0001$ \\
\hline Children ALP (IU/I) & $453 \pm 202$ & $407 \pm 123$ & \\
\hline Adolescents ALP (IU/I) & $596 \pm 227$ & $384 \pm 136$ & $<0.0001$ \\
\hline $25-(\mathrm{OH}) \mathrm{D}(\mathrm{nmol} / \mathrm{l})$ & $44 \pm 16$ & $36 \pm 12$ & 0.0001 \\
\hline
\end{tabular}

Significant differences between boarders and controls are noted (Student's unpaired $t$-test and Mann and Whitney $U$ test).

a Serum values of total calcium concentrations are corrected for protidemia. 
Table 3 Clinical characteristics as regards 25-(OH)D levels (mean \pm s.D.) in the boarding school cohort. Significant differences compared to values or prevalence observed with $25-(\mathrm{OH}) \mathrm{D}$ values $\leq 30 \mathrm{nmol} / \mathrm{l}$ are noted. Statistical tests were $\chi^{2}$-test for prevalence and unpaired $t$-test and Mann and Whitney $U$ test for age and anthropometry. Sex and pubertal maturation subgroups were too small ( $<30$ individuals) for $\chi^{2}$-analyses of prevalence.

\begin{tabular}{|c|c|c|c|c|}
\hline 25-(OH)D & Up to $30 \mathrm{nmol} / \mathrm{l}$ & $31-40 \mathrm{nmol} / \mathrm{l}$ & $41-50 \mathrm{nmol} / \mathrm{l}$ & $51-82 \mathrm{nmol} / \mathrm{l}$ \\
\hline$n$ & 47 & 67 & 53 & 59 \\
\hline 25-(OH)D (nmol/l) & $26.5 \pm 3.5$ & $35.6 \pm 2.8$ & $45.9 \pm 2.7$ & $65.2 \pm 12.0$ \\
\hline Age (years) & $11.8 \pm 1.9$ & $11.5 \pm 1.6$ & $11.3 \pm 2.0$ & $11.2 \pm 1.7$ \\
\hline Children $(n)$ & $9.9 \pm 1.1(20)$ & $10.2 \pm 0.9(33)$ & $9.7 \pm 1.2(29)$ & $10.2 \pm 1.1(36)$ \\
\hline Adolescents $(n)$ & $13.2 \pm 1.0(27)$ & $12.7 \pm 1.0(34)$ & $13.1 \pm 1.1(24)$ & $12.9 \pm 0.9(23)$ \\
\hline \multicolumn{5}{|l|}{ BMI (z-score) } \\
\hline Children & $-0.10 \pm 0.83$ & $-0.24 \pm 1.00$ & $-0.07 \pm 1.08$ & $0.07 \pm 0.88$ \\
\hline Adolescents & $-0.18 \pm 1.04$ & $-0.44 \pm 1.30$ & $-0.083 \pm 0.95$ & $-0.64 \pm 1.05$ \\
\hline \multicolumn{5}{|l|}{ Height ( $z$-score) } \\
\hline Children & $-0.20 \pm 0.91$ & $-0.62 \pm 0.86$ & $-0.50 \pm 0.97$ & $-0.42 \pm 0.87$ \\
\hline Adolescents & $-0.74 \pm 1.10$ & $-1.04 \pm 1.04$ & $-0.92 \pm 1.46$ & $-1.36 \pm 0.88$ \\
\hline \multicolumn{5}{|l|}{ Prevalence of } \\
\hline Genu valgum & $36 \%$ & $9 \%{ }^{0.0007}$ & $11 \%^{0.0042}$ & $7 \% 0.0002$ \\
\hline Children & $40 \%$ & $18 \%$ & $21 \%$ & $8 \%$ \\
\hline Adolescents & $33 \%$ & $0 \%$ & $0 \%$ & $4 \%$ \\
\hline Girls & $36 \%$ & $3 \%$ & $11 \%$ & $5 \%$ \\
\hline Boys & $37 \%$ & $11 \%$ & $11 \%$ & $7 \%$ \\
\hline Hypocalcemic seizure & $0 \%$ & $4 \%$ & $0 \%$ & $0 \%$ \\
\hline Respiratory & $8 \%$ & $4 \%$ & $2 \%$ & $8 \%$ \\
\hline Bone pain & $8 \%$ & $6 \%$ & $6 \%$ & $13 \%$ \\
\hline Scoliosis & $16 \%$ & $7 \%$ & $11 \%$ & $12 \%$ \\
\hline Dental caries & $8 \%$ & $9 \%$ & $13 \%$ & $8 \%$ \\
\hline Poor dental health & $85 \%$ & $83 \%$ & $79 \%$ & $83 \%$ \\
\hline Digestive symptoms & $71 \%$ & $64 \%$ & $68 \%$ & $46 \%$ \\
\hline Parasitosis & $55 \%$ & $43 \%$ & $53 \%$ & $47 \%$ \\
\hline
\end{tabular}

\section{Bow legs and other features associated with low vitamin D status}

To evaluate associations between vitamin D status and clinical, or biochemical, features, boarders were segregated on the basis of their serum 25-(OH)D levels using 30,40 , and $50 \mathrm{nmol} / \mathrm{l}$ cutoffs. Boarders with $25-(\mathrm{OH}) \mathrm{D}$ levels $\leq 30 \mathrm{nmol} / \mathrm{l}$ showed a high prevalence of bow legs $(36 \%)$, compared with boarders with $25-(\mathrm{OH}) \mathrm{D}$ levels between 31 and $40 \mathrm{nmol} / \mathrm{l}(9 \%)$, between 41 and $50 \mathrm{nmol} / \mathrm{l}(13 \%)$, or above $50 \mathrm{nmol} / \mathrm{l}(7 \%)$. This 25-(OH)D-dependent prevalence of genu varum/ valgum was not influenced by pubertal status and gender (Table 3). The prevalence of bow legs was too low in the control cohort ( 5 children, $7 \%$ of the cohort), and the size of the cohort was too small to enable association studies using the $25-(\mathrm{OH}) \mathrm{D}$ cutoffs. But none of the 28 controls with $25-(\mathrm{OH}) \mathrm{D}$ levels $\leq 30 \mathrm{nmol} / \mathrm{l}$ showed lower limb deformities.

Low 25-(OH)D levels (below or equal to $30 \mathrm{nmol} / \mathrm{l}$ ) were also associated with higher serum alkaline phosphatase activities in prepubertal boarders (Table 4). No such association was observed during puberty, alkaline phosphatase values being markedly high in the adolescent subgroup of boarders, irrespective of their 25-(OH)D levels (Tables 2 and 4). Again, no correlation was observed between serum alkaline

Table 4 Biology as regards 25-(OH)D levels in full-time boarders (mean \pm s.D.). Values significantly different from those observed with $25-(\mathrm{OH}) \mathrm{D}$ values higher than $50 \mathrm{nmol} / \mathrm{l}$ are noted (using pairwise unpaired $t$-test and Mann and Whitney $U$ test).

\begin{tabular}{|c|c|c|c|c|}
\hline 25-(OH)D (nmol/l) & $\begin{array}{l}\text { Up to } 30 \mathrm{nmol} / \mathrm{I} \\
(n=47)\end{array}$ & $\begin{array}{c}31-40 \mathrm{nmol} / \mathrm{l} \\
(n=67)\end{array}$ & $\begin{array}{c}41-50 \mathrm{nmol} / \mathrm{l} \\
(n=53)\end{array}$ & $\begin{array}{c}51-82 \mathrm{nmol} / \mathrm{I} \\
(n=59)\end{array}$ \\
\hline Proteins $(g / l)$ & $70 \pm 10$ & $67 \pm 10$ & $71 \pm 10$ & $69 \pm 12$ \\
\hline $\mathrm{Hb}(\mathrm{g} / \mathrm{l})$ & $11.0 \pm 1.1$ & $11.4 \pm 1.0$ & $11.4 \pm 1.0$ & $11.2 \pm 1.1$ \\
\hline Glucose $(\mathrm{mmol} / \mathrm{l})$ & $4.2 \pm 0.8$ & $4.0 \pm 0.8$ & $4.2 \pm 0.8$ & $4.2 \pm 0.8$ \\
\hline Children creatinine $(\mu \mathrm{mol} / \mathrm{l})$ & $44 \pm 14$ & $40 \pm 12$ & $41 \pm 12$ & $41 \pm 9$ \\
\hline Adolescents creatinine $(\mu \mathrm{mol} / \mathrm{l})$ & $60 \pm 14$ & $56 \pm 13$ & $59 \pm 12$ & $61 \pm 14$ \\
\hline Total Ca $(\mathrm{mmol} / \mathrm{l})$ & $2.10 \pm 0.26^{0.0205}$ & $2.12 \pm 0.30^{0.0340}$ & $2.11 \pm 0.33^{0.0259}$ & $2.24 \pm 0.32$ \\
\hline Corrected $\mathrm{Ca}(\mathrm{mmol} / \mathrm{l})$ & $2.15 \pm 0.28^{0.0083}$ & $2.22 \pm 0.31$ & $2.16 \pm 0.35^{0.0100}$ & $2.32 \pm 0.35$ \\
\hline Phosphates $(\mathrm{mmol} / \mathrm{l})$ & $1.33 \pm 0.34$ & $1.35 \pm 0.41$ & $1.37 \pm 0.38$ & $1.39 \pm 0.37$ \\
\hline Magnesium $(\mathrm{mmol} / \mathrm{l})$ & $0.70 \pm 0.14$ & $0.67 \pm 0.12$ & $0.71 \pm 0.14$ & $0.72 \pm 0.15$ \\
\hline Children ALP (IU/I) & $534 \pm 148^{0.0138}$ & $439 \pm 231$ & $432 \pm 187$ & $437 \pm 211$ \\
\hline Adolescents ALP (IU/I) & $596 \pm 228$ & $593 \pm 219$ & $633 \pm 244$ & $573 \pm 228$ \\
\hline
\end{tabular}


phosphatase and AST (or ALT) transaminase activities, neither before nor during puberty (data nor shown).

Finally, serum 25-(OH)D levels were positively associated with the serum calcium levels of boarders $(r=0.202, P=0.0024)$ : boarders with $25-(\mathrm{OH}) \mathrm{D}$ levels $\leq 30 \mathrm{nmol} / \mathrm{l}$, and even those with intermediate levels $(30-50 \mathrm{nmol} / \mathrm{l})$, had lower serum calcium levels than boarders with $25-(\mathrm{OH}) \mathrm{D}$ levels $>50 \mathrm{nmol} / \mathrm{l}$ (Table 4 ). In contrast, serum calcium was not associated with 25- $(\mathrm{OH}) \mathrm{D}$ levels in the control cohort, and boarders had significantly lower serum calcium than controls when their $25-(\mathrm{OH}) \mathrm{D}$ levels were $\leq 30 \mathrm{nmol} / \mathrm{l}(2.15$ \pm 0.28 vs $2.41 \pm 0.16 \mathrm{mmol} / \mathrm{l}, \quad P<0.0001)$, but not when their 25-(OH)D levels were above $50 \mathrm{nmol} / \mathrm{l}$ $(2.32 \pm 0.35$ vs $2.50 \pm 0.12 \mathrm{mmol} / \mathrm{l})$.

\section{Discussion}

Moderate leg bowing may be regarded as physiological in young children, aged $<2-5$ years, with first a varus followed by a valgus angulation at the knee joint (31). But this feature is transient in white North American (27), Nigerian (32), and Asian $(33,34)$ children, and bowing of the lower extremities is considered to be abnormal after the age of 7-8 years (32-34). Furthermore, $<2.5 \%$ of 196 North American white children, aged 6 months to 11 years, had knock-knees with an IM distance above $8 \mathrm{~cm}$ (27). Likewise, a European study of 427 adolescents aged 10-16 years showed a mean IM of $0-2 \mathrm{~cm}$, with a prevalence lower than $2.5 \%$ of IC above $4-5 \mathrm{~cm}$, and of IM above $4 \mathrm{~cm}$ in boys and $8 \mathrm{~cm}$ in girls (28). These observations contrast with the present findings of a high prevalence (15\%) of genu varum/genu valgum (IC or IM distances above $5 \mathrm{~cm}$ ) in a homogeneous cohort of 226 white European children and adolescents living in a Moldovan boarding school.

Abnormal leg bowing may result from rare diseases like hereditary rickets, osteogenesis imperfecta, or achondroplasia, but its pathogenesis habitually appears multifactorial, possibly involving genetic factors and several environmental contributors that are often associated: increased skin pigmentation, insufficient exposure to sunshine, atmospheric pollution, high fluoride content of the drinking water, low milk/dairy product intakes and/or calcium deficiency, and high fiber and/or low meat intakes $(11,18-24)$.

Low vitamin D status likely contributed to the genesis of lower limb deformities in the present cohort, as bow legs or knock-knees were found in $36 \%$ of the full-time boarders seen during winter-spring with $25-(\mathrm{OH}) \mathrm{D}$ levels $\leq 30 \mathrm{nmol} / \mathrm{l}$, whatever their sex or pubertal maturation, and only in $10 \%$ of those with $25-(\mathrm{OH}) \mathrm{D}$ levels in the intermediate $30-50 \mathrm{nmol} / \mathrm{l}$ range, and in $7 \%$ of those with higher levels.

The 25- $(\mathrm{OH}) \mathrm{D}$ status was also associated with markers of calcium and bone metabolism, namely serum alkaline phosphatase and serum calcium. Prepubertal children with $25-(\mathrm{OH}) \mathrm{D}$ levels $\leq 30 \mathrm{nmol} / \mathrm{l}$ had increased serum alkaline phosphatase activities, with no simultaneous increase in transaminase activity, thus suggesting underlying rickets even though this could not be confirmed because bone X-rays had not been performed for ethical reasons. No such association was observed in adolescent boarders, but it should be noted that their serum alkaline phosphatase activities, irrespective of their serum 25-(OH)D levels, were in the range of the prepubertal boarders with a low vitamin D status, which was higher than that measured in agematched controls. The lack of association with serum transaminase activities suggests that the high alkaline phosphatase activities found in boarders during puberty reflect an increased bone turnover, possibly due to calcium deficiency. But measurements of serum PTH, bone resorption markers, and/or bone mineral densitometry are clearly needed to test this hypothesis. Finally, 25-(OH)D levels were positively associated with serum calcium levels, with optimal 25-(OH)D levels above $50 \mathrm{nmol} / \mathrm{l}$. No association was found with calcium-dependent clinical symptoms, hypocalcemic fits especially, probably because boarders were older and/or because their hypocalcemia and vitamin D deficiency were moderate, compared to previously reported cases $(26,35)$. Vitamin D status varies with the season in temperate countries, being lower during winter-spring when the u.v. energy in the solar light becomes insufficient for the skin production of vitamin $D$. The present association study unmasks a possibly higher risk for low vitamin D status in girls and shows that a low 25-(OH)D status level, whether or not only in winter-spring, clearly aggravates the prevalence of lower limb deformities and of low serum calcium in children and adolescents of European origin.

Yet low vitamin D status was not the sole contributor to the high prevalence of lower limb deformities and to the lower serum calcium levels observed in the boarding school. First, the full-time boarders living in a rural setting had a vitamin D status higher, between January and April, than Moldovan controls living in Chisinau city. Second, the $22 \%$ incidence of $25-(\mathrm{OH}) \mathrm{D}$ values $\leq 30 \mathrm{nmol} / \mathrm{l}$ observed during winter-spring in the boarding school was comparable to that reported in other European countries (17-35\%) located at similar latitudes $\left(46^{\circ}-51^{\circ} \mathrm{N}\right)$, namely France, Germany, and Switzerland (1-3). Third, the prevalence of lower limb deformities in boarders with $25-(\mathrm{OH}) \mathrm{D}$ values $\leq 30 \mathrm{nmol} / \mathrm{l}$ was markedly higher (36 vs $0 \%$ ), and the serum levels of calcium were significantly lower, than in white Moldovan controls with a similarly low 25-(OH)D status. Digestive disorders or parasitic infections may have aggravated the risk of lower limb deformities, but their prevalence, similar in the two Moldovan cohorts, cannot per se explain the anomalies found in the boarding school. Fluoride intoxication has not been evaluated, but cannot be excluded as an additional 
contributor, as suggested by reports of children with rachitic-like bone deformities in regions of endemic fluorosis $(11,18,21)$ and observations of high fluoride levels in potable water in some Moldovan districts (36). But a major contributor was likely the cereal-based diet with little access to meat, milk, and dairy products, an unusual diet for Moldovan children, including the urban controls, who theoretically receive adequate calcium/milk intakes $(37,38)$. In agreement with this hypothesis, low calcium/milk intakes have been associated with rickets, even in the absence of severe vitamin $\mathrm{D}$ deficiency, in some regions of Nigeria and Bangladesh $(11,23)$, and low meat and high fiber intakes have been associated with an increased rachitic and osteomalacic relative risk in the UK (39).

In conclusion, there is an emerging evidence that a very low calcium intake may contribute to the etiology of rickets in Africa and Asia (23), and that calcium deficiency may lower the threshold under which vitamin D status becomes insufficient to ensure the optimal mineralization of the growing skeleton in children (11) and adolescents (2). The present findings show that lower limb deformities and low serum calcium may be frequent in subsets of Caucasian children and adolescents and highlight the major impact of combined calcium/milk and vitamin D deficiency on bone mineralization during pre-pubertal and pubertal growth. In the presence of risk factors like low calcium/milk intakes, possibly aggravated by intestinal malabsorption and parasitosis, optimal 25-(OH)D levels for bone health and calcium metabolism appear to be higher than $30 \mathrm{nmol} / \mathrm{l}$, and possibly higher than $50 \mathrm{nmol} / \mathrm{l}$, in agreement with thresholds proposed earlier for optimal bone mass accrual during growth $(2,6,8,16,40)$. Because of the high prevalence of low $25-(\mathrm{OH}) \mathrm{D}$ levels $(\leq 30 \mathrm{nmol} / \mathrm{l})$ during winter-spring, dietary fortification, or supplementation with vitamin $\mathrm{D}$, may be recommended, at least during the winter, to European children and adolescents with no or insufficient calcium/dairy product intakes.

\section{Declaration of interest}

The authors declare that there is no conflict of interest that could be perceived as prejudicing the impartiality of the research reported.

\section{Funding}

The present study was supported in part by a research grant from the Société Française de Nutrition (2006).

\section{Author contribution statement}

M Garabedian, L Esterle, and A Voloc conceived and designed the experiments. A Voloc recruited the cohort and clinically examined the children. L Esterle, T M Nguyen, O Walrant-Debray, and A Colofitchi performed the experiments. L Esterle and M Garabedian analyzed the data. L Esterle and M Garabedian wrote the paper.

\section{Acknowledgements}

The authors wish to thank the boarders, their teachers, and all the medical staff of the Chisinau Hospital who kindly and eagerly collaborated to the study.

\section{References}

1 Ginty F, Cavadini C, Michaud PA, Burckhardt P, Baumgartner M, Mishra GD \& Barclay DV. Effects of usual nutrient intake and vitamin D status on markers of bone turnover in Swiss adolescents. European Journal of Clinical Nutrition 200458 1257-1265. (doi:10.1038/sj.ejcn.1601959)

2 Esterle L, Nguyen TM, Walrant-Debray O, Sabatier JP \& Garabedian M. Adverse interaction of low calcium diet and low 25- $(\mathrm{OH}) \mathrm{D}$ levels on lumbar spine mineralization in late-pubertal girls. Journal of Bone and Mineral Research, 2010. (doi:10.1002/ jbmr.134)

3 Hintzpeter B, Scheidt-Nave C, Müller MJ, Schenk L \& Mensink GB. Higher prevalence of vitamin D deficiency is associated with immigrant background among children and adolescents in Germany. Journal of Nutrition 2008138 1482-1490.

4 Andersen R, Mølgaard C, Skovgaard LT, Brot C, Cashman KD, Chabros E, Charzewska J, Flynn A, Jakobsen J, Kärkkäinen M, Kiely M, Lamberg-Allardt C, Moreiras O, Natri AM, O'brien M, Rogalska-Niedzwiedz M \& Ovesen L. Teenage girls and elderly women living in northern Europe have low winter vitamin D status. European Journal of Clinical Nutrition 200559 533-541. (doi:10.1038/sj.ejcn.1602108)

5 Hill TR, Cotter AA, Mitchell S, Boreham CA, Dubitzky W, Murray L, Strain JJ, Flynn A, Robson PJ, Wallace JM, Kiely M \& Cashman KD. Vitamin D status and its determinants in adolescents from the Northern Ireland Young Hearts 2000 cohort. British Journal of Nutrition 200899 1061-1067. (doi:10.1017/ S0007114507842826)

6 Cheng S, Tylavsky F, Kröger H, Kärkkäinen M, Lyytikäinen A, Koistinen A, Mahonen A, Alen $M$, Halleen J, Väänänen $K$ \& Lamberg-Allardt C. Association of low 25-hydroxyvitamin D concentrations with elevated parathyroid hormone concentrations and low cortical bone density in early pubertal and prepubertal Finnish girls. American Journal of Clinical Nutrition 200378 485-492.

7 Jones G, Dwyer T, Hynes KL, Parameswaran V \& Greenaway TM. Vitamin D insufficiency in adolescent males in Southern Tasmania: prevalence, determinants, and relationship to bone turnover markers. Osteoporosis International 200516 636-641. (doi:10.1007/s00198-004-1733-z)

8 Outila TA, Kärkkäinen MU \& Lamberg-Allardt CJ. Vitamin D status affects serum parathyroid hormone concentrations during winter in female adolescents: associations with forearm bone mineral density. American Journal of Clinical Nutrition $2001 \mathbf{7 4}$ 206-210.

9 Rizzoli R, Bianchi ML, Garabedian M, McKay HA \& Moreno LA. Maximizing bone mineral mass gain during growth for the prevention of fractures in the adolescents and the elderly. Bone 201046 294-305. (doi:10.1016/j.bone.2009.10.005)

10 Raiten DJ \& Picciano MF. Vitamin D and health in the 21st century: bone and beyond. Executive summary. American Journal of Clinical Nutrition 200480 (Supplement 6) 1673S-1677S.

11 Pettifor JM. Vitamin D and/or calcium deficiency rickets in infants and children: a global perspective. Indian Journal of Medical Research 2008127 245-249.

12 Greer FR. Issues in establishing vitamin D recommendations for infants and children. American Journal of Clinical Nutrition 2004 80 (Supplement 6) 1759S-1762S.

13 Dawson-Hughes B, Mithal A, Bonjour JP, Boonen S, Burckhardt P, Fuleihan GE, Josse RG, Lips P, Morales-Torres J \& Yoshimura N. 
IOF position statement: vitamin D recommendations for older adults. Osteoporosis International 201021 1151-1154. (doi:10. 1007/s00198-010-1285-3)

14 Guillemant J, Le HT, Maria A, Allemandou A, Pérès G \& Guillemant S. Wintertime vitamin D deficiency in male adolescents: effect on parathyroid function and response to vitamin D3 supplements. Osteoporosis International $2001 \quad \mathbf{1 0} \quad 875-879$. (doi:10.1007/s001980170040)

15 Harkness L \& Cromer B. Low levels of 25-hydroxy vitamin D are associated with elevated parathyroid hormone in healthy adolescent females. Osteoporosis International 200516 109-113. (doi:10.1007/s00198-004-1656-8)

16 Cashman KD, Hill TR, Cotter AA, Boreham CA, Dubitzky W, Murray L, Strain J, Flynn A, Robson PJ, Wallace JM \& Kiely M. Low vitamin D status adversely affects bone health parameters in adolescents. American Journal of Clinical Nutrition $2008 \mathbf{8 7}$ 1039-1044.

17 Carter GD, Jones JC \& Berry JL. The anomalous behavior of exogenous 25-hydroxyvitamin D in competitive binding assays. Journal of Steroid Biochemistry and Molecular Biology $2007 \mathbf{1 0 3}$ 480-482. (doi:10.1016/j.jsbmb.2006.11.007)

18 Khandare AL, Harikumar R \& Sivakumar B. Severe bone deformities in young children from vitamin $\mathrm{D}$ deficiency and fluorosis in Bihar-India. Calcified Tissue International $2005 \mathbf{7 6}$ 412-418. (doi:10.1007/s00223-005-0233-2)

19 Echarri JJ, Bazeboso JA \& Guillém-Grima F. Rachitic deformities of lower members in congolese children. Anales del Sistema Sanitario de Navarra 200831 235-240. (doi:10.4321/S1137-6627200 $8000500003)$

20 Fraser DR. Vitamin D-deficiency in Asia. Journal of Steroid Biochemistry and Molecular Biology 2004 89-90 491-495. (doi:10.1016/j.jsbmb.2004.03.057)

21 Teotia SPS \& Teotia M. Nutritional bone disease in Indian population. Indian Journal of Medical Research 2008127 219-228.

22 Schnitzler CM, Pettifor JM, Patel D, Mesquita JM, Moodley GP \& Zachen D. Metabolic bone disease in black teenagers with genu valgum or varum without radiologic rickets: a bone histomorphometric study. Journal of Bone and Mineral Research 19949 479-486. (doi:10.1002/jbmr.5650090407)

23 Prentice A. Vitamin D deficiency: a global perspective. Nutrition Reviews 200866 (10 Supplement 2) S153-S164. (doi:10.1111/j. 1753-4887.2008.00100.x)

24 Craviari T, Pettifor JM, Thacher TD, Meisner C, Arnaud J, Fishcher PR \& Rickets Convergence Group. Rickets: an overview and future directions, with special reference to Bangladesh. A summary of the Rickets Convergence Group meeting, Dhaka, 26-27 January 2006. Journal of Health, Population, and Nutrition 200826 112-121.

25 Robinson PD, Högler W, Craig ME, Verge CF, Walker JL, Piper AC, Woodhead HJ, Cowell CT \& Ambler GR. The re-emerging burden of rickets: a decade of experience from Sydney. Archives of Disease in Childhood 200691 564-568. (doi:10.1136/adc.2004.069575)

26 Ladhani S, Srinivason L, Buchanan C \& Allgrove J. Presentation of vitamin D deficiency. Archives of Disease in Childhood $2004 \mathbf{8 9}$ 781-784. (doi:10.1136/adc.2003.031385)
27 Heath $\mathrm{CH} \&$ Staheli LT. Normal limits of knee angle in white children - genu varum and genu valgum. Journal of Pediatric Orthopaedics 199313 259-262.

28 Cahuzac JP, Vardon D \& Sales de Gauzy J. Development of the clinical tibiofemoral angle in normal adolescents. Journal of Bone and Joint Surgery. British Volume 1995 77-B 729-732.

29 De Onis M, Onyango AW, Borghi E, Siyam A, Nishida C \& Siekmann J. Development of a WHO growth reference for schoolaged children and adolescents. Bulletin of the World Health Organization 200785 660-667. (doi:10.2471/BLT.07.043497)

30 Carter GD, Carter CR, Gunter E, Jones J, Jones G, Makin HL \& Sufi S. Measurement of vitamin D metabolites: an international perspective on methodology and clinical interpretation. Journal of Steroid Biochemistry and Molecular Biology 2004 89-90 467-471. (doi:10.1016/j.jsbmb.2004.03.055)

31 Salenius P \& Vankka E. The development of the tibiofemoral angle in children. Journal of Bone and Joint Surgery. American Volume 197557 259-261.

32 Omololu B, Tella A, Ogunlade SO, Adevemo AA, Adebisi A, Alonge TO, Salawu SA \& Akinpelu AO. Normal values of knee angle, intercondylar and intermalleolar distances in Nigerian children. West African Journal of Medicine 200322 301-304.

33 Cheng JC, Chan PS, Chiang SC \& Hui PW. Angular and rotational profile of the lower limb in 2,630 Chinese children. Journal of Pediatric Orthopaedics 199111 154-161.

34 Yoo JH, Choi IH, Cho TJ, Chung CY \& Yoo WJ. Development of tibiofemoral angle in Korean children. Journal of Korean Medical Science 200823 714-717. (doi:10.3346/jkms.2008.23.4.714)

35 Narchi H, El Jamil M \& Kulaylat N. Symptomatic rickets in adolescence. Archives of Disease in Childhood 200184 501-503. (doi:10.1136/adc.84.6.501)

36 Toma S, Kreidman J, Vedina O \& Veliksar S. Some observations on fluoride problems in the Moldova Republic. Fluoride 199932 $67-70$.

37 Indrei LL, Albu A, Albu M, Dănilă L \& Foia I. Assessment of food intake in rural area school children. Revista Medico-Chiruricala A Societatii de Medici si Naturalisti Din Iasi 2003107 618-621.

38 Albu A, Indrei LL, Gavăt V, Petrariu FD \& Albu M. Specifics of food intake by schoolchildren in the rural areas of Moldova. Revista Medico-Chiruricala A Societatii de Medici si Naturalisti Din Iasi 2005 109 153-157.

39 Dunnigan MG, Henderson JB, Hole DJ, Mawer BE \& Berry JL. Meat consumption reduces the risk of nutritional rickets and osteomalacia. British Journal of Nutrition $200594983-991$. (doi:10.1079/BJN20051558)

40 Lehtonen-Veromaa MK, Möttönen TT, Nuotio IO, Irjala KM, Leino AE \& Viikari JS. Vitamin D and attainment of peak bone mass among peripubertal Finnish girls: a 3-y prospective study. American Journal of Clinical Nutrition $2002 \mathbf{7 6} 1446-1453$.

Received 23 August 2010

Accepted 25 August 2010 